\title{
PROFILES OF CONSUMER INNOVATIVENESS IN TURKEY
}

\author{
DOI: 10.17261/Pressacademia.2018.967 \\ JMML- V.5-ISS.3-2018(8)-p.236-245
}

\author{
Sukru Akdogan ${ }^{1}$, Kumru Uyar ${ }^{2}$, Kenan Gullu ${ }^{3}$ \\ ${ }^{1}$ Erciyes University, Faculty of Economics and Administrative Sciences, Kayseri, Turkey. \\ akdogans@erciyes.edu.tr, ORCID: 0000-0001-6811-706X \\ ${ }^{2}$ Nuh Naci Yazgan University, Faculty of Economics and Administrative Sciences, Kayseri, Turkey. \\ kuyar@nny.edu.tr, ORCID: 0000-0002-2604-5317 \\ ${ }^{3}$ Erciyes University, Faculty of Tourısm, Kayseri, Turkey. \\ kgulluerciyes@edu.tr, ORCID: 0000-0002-8604-8798
}

Date Received: July 17, 2018

Date Accepted: September 12, 2018

To cite this document

Akdogan, S., Uyar, K., Gullu, K. (2018). Profiles of consumer innovativeness in Turkey. Journal of Management, Marketing and Logistics (JMML), V.5(3), p.236-245.

Permemant link to this document: http://doi.org/10.17261/Pressacademia.2018.967

Copyright: Published by PressAcademia and limited licenced re-use rights only.

\begin{abstract}
Purpose- This research examines the relationship between innovativeness, market mavens, and opinion leadership. The issue has been reevaluated in this study because of conflicting results between innovation and demographic variables in the past literature.

Methodology- The data was obtained from a survey of a convenience sample of 283 consumers from the city of Kayseri, Turkey. Data was analyzed through a Statistical Packet Program and the relationships were tested through correlation analyses.

Findings- Consumer innovation has a negative correlation with price sensitivity and a positive correlation with attitudes. Market mavens has a negative correlation with attitudes and affective responses, but it has positive correlation with price sensitivity. Opinion leadership has a positive correlation with price sensitivity.

Conclusion- As a result of the research, it was revealed consumers with a high level of innovation have low price sensitivity. market mavens and opinion leaders have higher price sensitivity.
\end{abstract}

Keywords: Consumer innovativeness, market maven, opinion leadership, consumer, Turkey.

JEL Classification: M00, M30, M31

\section{INTRODUCTION}

According to Feick and Price (1987) interpersonal influence is distinguished by four types of influential consumers: opinion leaders, early purchasers, general marketplace influencers, and market mavens. The classification that is commonly used today for influential consumers was developed by Clark and Goldsmith (2005) and includes innovators, opinion leaders, and market mavens. These concepts are important for the success of new products. The concept of consumer innovation is usually examined in the literature in two dimensions, innate innovativeness and domain specific innovativeness. Innate innovativeness refers to a general innovation level. There is the attitude that the individual is innate to innovations and that it is a personality characteristic (Midgley \& Dowling, 1978: 229). Goldsmith and Hofacker (1991) conceptualized and measured consumer innovativeness at the product category level, describing domain specific innovativeness. Domain specific innovativeness is the level of innovation that a consumer has for a particular product category (Goldsmith \& Flynn, 1993: 378, Hirunyawipada \& Paswan, 2006: 182; Goldsmith \& Foxall, 2003: 321; Bartels \& Reinders, 2011). Accordingly, the level of innovation for each product or product category of the consumer may vary. The present study focused on consumer innovativeness at the general concept. Variables that may be related to innovation and the effects of these variables were investigated. 


\section{LITERATURE REVIEW}

\subsection{Consumer Innovation}

Consumer innovation is an important concept in understanding the acceptance of new products (Hong et al., 2017: 265). Consumer innovation can be defined as the tendency to purchase new and different products and brands (Steenkamp, Hofstede \& Wedel, 1999: 56; Tellis, Yin \& Bell, 2009: 2). Innovative consumers accept innovations earlier than other members do in their social system and other consumers in the marketplace (Rogers \& Shoemaker, 1971: 27; Foxall, Goldsmith \& Brown, 1998: 41; Wedel, 1999: 56; Lin et al., 2017: 265). Midgley \& Dowling (1978: 236) defined consumer innovation as consumers not being affected by people when making a decision about innovation and perception of new ideas. The Diffusion of Innovation (DOI) Theory, developed by E.M. Rogers in 1962, is defined in five categories on the basis their innovativeness. These are: (1) innovators, (2) early adopters, (3) early majority, (4) late majority, and (5) laggards. Consumer innovation is closely related to personality traits (Goldsmith et al., 2003: 30; Bartels \& Reinders, 2011: 163), social values, and the economic situation of a person (Xie \& Singh, 2007: 240). Innovative consumers do not hesitate to take more risks and for them, sociability is a priority. In addition, they have extensive knowledge about products (White et al., 1987: 420).

Some studies provide evidence that consumer innovation is related to consumer gender (Goldsmith, Stith \& White, 1987; Ferreira \& Neves, 2014; Laukkanen, 2016) age (Labay \& Kinnear, 1981; Dickerson \& Gentry, 1983, Gilly \& Zeithaml, 1985; Martinez \& Flavian 1998; Ferreira \& Neves, 2014; Laukkanen, 2016), income (Labay \& Kinnear,1981; Dickerson \& Gentry, 1983; Martinez \& Flavian 1998; Steenkamp \& Burgess, 2002; Blake, Neuendorf \& Valdiserri, 2003; Porter \& Donthu, 2006; Mann \& Sahni, 2012; Ferreira \& Neves, 2014) education, (Labay \& Kinnear,1981; Dickerson \& Gentry, 1983) and occupational status (Labay \& Kinnear,1981; Dickerson \& Gentry, 1983). There are conflicting results about the direction of these relationships. In previous studies, the direction of the relationships between consumer innovation and several demographic characteristics show ambiguous results. Previous findings show that women (Goldsmith, Stith \& White, 1987; Goldsmith \& Newell, 1997), men (Goldsmith, Kim, Flynn \& Kimm, 2005; Tellis, Yin \& Bell, 2009), those highly educated (Goldsmith, Moore \& Beaudoin, 1999; Steenkamp \& Burgess 2002; Blake, Neuendorf \& Valdiserri, 2003; Shih \& Venkatesh, 2004; Lennon, Kim, Johnson, Jolly, Damhorst \& Jasper, 2007), younger people (Steenkamp et al., 1999; Tellis, Yin \& Bell, 2009; Uhl, Andrus, \& Poulsen, 1970; Venkatraman, 1991; Labay \& Kinnear 1981; Dickerson \& Gentry, 1983; Gilly \& Zeithaml, 1985; Martinez, Polo \& Flavian, 1998; Im, Bayus \& Mason, 2003; Goldsmith, Flynn \& Goldsmith, 2003; Goldsmith, Kim, Flynn \& Kimm, 2005; Clark \& Goldsmith, 2006; Goldsmith, Clark \& Goldsmith, 2006), older aged people (Steenkamp \& Burgess, 2002; Vandecasteele \& Geuens, 2010), richer people (Labay \& Kinnear, 1981; Dickerson \& Gentry, 1983; Martinez \& Flavian 1998; Im, Bayus \& Mason, 2003), and those with low income (Porter \& Donthu, 2006; Mann \& Sahni, 2012), all report greater innovativeness than others. However, in some studies, such a relationship could not be established (Ostlund 1974; Flynn \& Goldsmith, 1993). It was determined that there is no relationship with gender (Clark \& Goldsmith, 2006; Goldsmith, Clark \& Goldsmith, 2006), age (Goldsmith, Moore \& Beaudoin, 1999; Vandecasteele \& Geuens, 2010), education (Im, Bayus and Mason 2003), or income (Lennon et al., 2007; Laukkanen, 2016).

$H_{1}$ : There is a statistically significant relationship between Consumers Innovation and demographic variables.

$H_{1 a}$ : There is a statistically significant relationship between Consumers Innovation and the Gender of consumers.

$H_{1 b}$ : There is a statistically significant relationship between Consumers Innovation and the Income of consumers.

$H_{1 c}$ : There is a statistically significant relationship between Consumers Innovation and the Marital Status of consumers.

$H_{1 d}$ : There is a statistically significant relationship between Consumers Innovation and the Education of consumers.

$\mathrm{H}_{1 e}$ : There is a statistically significant relationship between Consumers Innovation and the Age of consumer.

Price sensitivity is how consumers react to price levels and price changes. Goldsmith and Newell (1997: 164) explain price sensitivity as an individual difference that explains how individual consumers react to price levels and changes in price levels. According to Goldsmith and Newell (1997) a consumer high in price sensitivity will manifest much less demand as price goes up (or higher demand as price goes down) and consumers low in price sensitivity will not react as strongly to a price change. Price insensitive consumers are willing to pay higher prices and are more willing to buy if prices go up (Foxall \& James, 2003; Shimp, Dunn, \& Klein, 2004). Innovator consumers are willing to pay premium prices of new products (Bearden et al., 1995: 287; Kotler, 1994: 493; Goldsmith, Kim, Flynn, \& Kim, 2005: 502). Goldsmith (1996) studied innovativeness and price sensitivity for a service category. He reported a significant negative correlation between scores on innovativeness and price sensitivity. Further work has been achieved in results that support it (Goldsmith \& Newell, 1997; Goldsmith, 1999; Goldsmith, Flynn \& Goldsmith, 2003; Pagani, 2007).

Thus, we expect innovativeness to determine price sensitivity.

$\mathrm{H}_{2}$ : There is a statistically significant relationship between Consumers Innovation and Price Sensitivity. 
Research suggests that people who hold more positive attitudes toward innovation are more likely to adapt (Bagozzi 1992; Claudy, Garcia \& O'Driscoll, 2015). Fort-Rioch \& Ackermann, (2013) found that Consumer innovativeness has a significantly positive effect on the attitude towards a new product.

We thus postulate that:

$\mathrm{H}_{3}$ : There is a statistically significant relationship between Consumers Innovation and Attitudes.

\subsection{Opinion Leaders}

According to Feick and Price (1987), opinion leaders that follow information about the product or service are intervening between mass media and the opinions and choices of target consumers. Opinion leaders are people with a source of personal influence that can influence consumers in a particular product group (Clark \& Goldsmith, 2005; Goodey \& East, 2008). Opinion leaders are capable of influencing other consumers in the consumer buying process (Flynn, Goldsmith \& Eastman, 1996). It is the informal influence that one person (the opinion leader) has on the actions of opinion seekers or receivers (Shiffman, O'Cass, Paladino, \& Carlson, 2014). Opinion leaders regularly share information they have with other consumers (Brancaleone \& Gountas, 2007). They often have a substantial effect on the diffusion of a product throughout its target market. The opinion leader is defined as a degree of influence a person has upon others based on his superior knowledge (Childers, 1986; Goldsmith \& De Witt, 2003; Eiamkanchanalai \& Assarut, 2016). Opinion leadership is limited to the product class. There are findings that there may be opinion leaders in multiple product categories, but there is no general opinion leadership (Feick \& Price, 1987). Opinion leaders have been found to be particularly persuasive when their recommendations are based on experience attributes, especially if the product is complex (Jain \& Posavac, 2001). Opinion leaders tend to be socially active, self-confident (Baumgarten, 1975; Venkatraman, 1989), and consumers of mass media (Rogers, 1983; Summers, 1970). Opinion leaders use different sources of information compared to opinion seekers (Shoham \& Ruvio, 2008). They read more, are more knowledgeable of new product developments in a category, and participate more in related consumer activities (Corey, 1971). Because opinion, leaders do not represent commercial interests, their opinions pass as being more reliable than those directly coming from marketers (Rogers, 2003). These consumers are therefore very important to marketers in distributing product information. Past studies have revealed demographic features that define opinion leaders. According to literature, opinion leaders typically have been characterized as younger, having a higher education, and having a higher income (Assael 1984; Gatignon \& Robertson, 1985; Midgley \& Dowling, 1978; Myers \& Robertson, 1972; Sarathy \& Patro, 2013). Duvel and Williams (2005) suggested that opinion leadership is influenced by age, marital status, and gender.

Thus,

$\mathrm{H}_{4}$ : There is a statistically significant relationship between Opinion Leadership and demographic variables.

$H_{4 a}$ : There is a statistically significant relationship between Opinion Leadership and the Gender of consumers.

$H_{4 b}$ : There is a statistically significant relationship between Opinion Leadership and the Income of consumers.

$H_{4 c}$ : There is a statistically significant relationship between Opinion Leadership and the Marital Status of consumers.

$H_{4 d}$ : There is a statistically significant relationship between Opinion Leadership and the Education of consumers.

$\mathrm{H}_{4 e}$ : There is a statistically significant relationship between Opinion Leadership and the Age of consumers.

According to Rogers, (1995) one way to become an opinion leader is to consistently own contemporary models of a product. Studies have tried to examine the relationship between opinion leadership and innovativeness. Innovativeness has been found to be positively correlated with opinion leadership (Hurt, Joseph \& Cook, 1977; Dickerson \& Gentry, 1983; Goldsmith \& Flynn, 1992; Goldsmith et al, 1996; Goldsmith et al. 1997; Grewal, Mehta \& Kardes, 2000; Goldsmith, 2001; Vishwanath, 2005; Girardi, Soutar \& Ward, 2005; Sun, Youn, Wu \& Kuntaraporn, 2006; Jordaan \& Simpson, 2006; Ruvio \& Shoham, 2007; Shoham \& Ruvio, 2008; Hoffmann \& Soyez, 2010; Sarathy, 2011).

Thus,

$H_{5}$ : There is a statistically significant relationship between Consumers Innovation and Opinion Leadership.

$H_{6}$ : There is a statistically significant relationship between Opinion Leadership and Price Sensitivity.

$H_{7}$ : There is a statistically significant relationship between Opinion Leadership and Attitudes. 


\subsection{Market Mavens}

Feick and Price (1987) first defined market mavens as individuals, who highly involved in the marketplace and represent an important source of marketplace information to other consumers. Market mavens are marketplace influencers, whose influence is based on more general market knowledge and expertise. Market mavens have a high level of information about products /service and market (Bidar, Watson, \& Barros, 2016: 332). Mavens are knowledgeable about many products, and their marketing mix. Market mavens are different compared to other types of consumers since they focus on the needs of others (not only their own) and have a lot to say about it. Market mavens are an important target market because of their influence on the buying decisions of other consumers, who seek and receive their advice (Williams \& Slama, 1995: 4). Market mavens do not need to be the first users of these products. Consumer innovativeness appears more focused on new products, while market mavens are more interested in learning and communicating information about the market place in general (Goldsmith, Flynn \& Goldsmith, 2003: 56). According to Walsh and Mitchell (2000) market mavens are perfectionists. They help spread reputation and support others by sharing experiences (Romero \& Molina 2011). According to Walsh, Gwinner, and Swanson (2004), market mavens are motivated by a sense of obligation to share information, a desire to help others, and gain feelings of pleasure associated with informing others about new products. Both opinion leaders and market mavens may enjoy accumulating social capital when they share their market knowledge with acquaintances (Stokburger-Sauer \& Hoyer, 2009). The characteristics of market mavens are quite similar compared to those of opinion leaders, though the difference is that market mavens are a source of information about the marketplace in general (Feick\& Price, 1987; Wiedmann, Walsh \& Mitchell, 2001; Ruvio \& Shoham, 2007, 705). Steenkamp and Gielens (2003) called market mavens generalized opinion leaders for this difference. Different results have been obtained in literature, which has examined the relationship with market mavens and demographic characteristics. Women (Feick \& Price, 1987; Williams \& Slama, 1995; Walsh et al, 2002; Goldsmith et al.; 2006; Goodey \& East, 2008; Flynn \& Goldsmith, 2017), men (Abratt et al., 1995), younger people (Feick \&Price, 1987; Williams \& Slama, 1995; Wiedmann et al, 2001; Walsh et al, 2002; Chelminski \& Coulter, 2002; Goldsmith et al., 2006; Goodey and East, 2008; Flynn \& Goldsmith, 2017), and less educated people (Feick \& Price, 1987; Higie, Feick, \& Price, 1987; Williams \& Slama, 1995; Goodey \& East, 2008) showed significantly higher market maven scores than others. However, Goldsmith et al. (2006) found that in identifying market mavens, it was determined that demographic characteristics were not determinants. Some prior research determined that there was no relationship with gender (Wiedmann et al, 2001; Chelminski \& Coulter, 2002; Brancaleone \& Gountas, 2007; Goodey \& East, 2008), age (Feick \& Price, 1987; Higie et al.,1987; Slama \& Williams, 1990, Wiedmann, Walsh \& Mitchell, 2001; Gountas, 2007; Goodey \& East, 2008), education (Higie et al.,1987; Slama \& Williams, 1990; Wiedmann, Walsh, \& Mitchell, 2001; Chelminski \& Coulter, 2002),or income (Chelminski \& Coulter, 2002; Gountas, 2007; Goodey \& East, 2008).

$H_{8}$ : There is a statistically significant relationship between Market mavens and demographic variables.

$H_{8 a}$ : There is a statistically significant relationship between Market mavens and the Gender of consumers.

$H_{8 b}$ : There is a statistically significant relationship between Market mavens and the Income of consumers.

$H_{8 c}$ : There is a statistically significant relationship between Market mavens and the Marital Status of consumers.

$H_{8 d}$ : There is a statistically significant relationship between Market mavens and the Education of consumers.

$H_{8 e}$ : There is a statistically significant relationship between Market mavens and the Age of consumers.

Goldsmith et al. (2006) have concluded that being innovative in defining market mavens is explanatory. Market mavens have both new and old products in their field of interest, whereas innovators tend to concentrate primarily on the new (Andrews \& Benedicktus, 2015: 224). One explanation for some mavens not being consumer innovators is that some mavens may be more change resistant than others. Mavens that are less resistant to change may be more likely to exhibit consumer innovativeness in their buying decisions (Andrews \& Benedicktus, 2015: 224). Innate innovativeness has been found to be positively correlated with market mavens (Goldsmith, Clark \& Goldsmith, 2006). Domain specific innovativeness has been found to be positively correlated with market mavens (Goldsmith \& Flynn, 1992; Ruvio \& Shoham, 2007). Ruvio and Shoham (2007, 704) stated that innovative consumers are more likely to be opinion leaders and mavens than less innovative ones. It is possible that maven consumers are probably more innovative. According to Ruvio and Shoham (2007), mavenism is positively associated with general opinion leadership. Market mavens are also positively related to opinion leadership (Engelland, Hopkins \& Larson, 2001; Clark \& Goldsmith, 2005). Goodey and East (2008) showed that mavenism was related to price consciousness.

In the light of the literature, we argue that;

$\mathrm{H}_{9}$ : There is a statistically significant relationship between Consumer Innovativeness and Market Mavens.

$H_{10}$ : There is a statistically significant relationship between Market Mavens and Opinion Leaders.

$H_{11}$ : There is a statistically significant relationship between Market Mavens and Price Sensitivity.

$H_{12}$ : There is a statistically significant relationship between Market Mavens and Attitudes. 


\section{DATA AND METHODOLOGY}

\subsection{Aim of the Research}

The aim of this study was to examine the empirical link between consumer innovativeness, market mavens, and opinion leadership. In this respect, this study investigated these in the city of Kayseri, in Turkey. In addition, the relationship between these dependent variables and demographic characteristics was also examined.

\subsection{Research Method}

The data was collected by means of a questionnaire that was the result of an extensive pilot study. We used the convenience sampling method and collected 350 responses in Turkey. We excluded from our analysis, responses with missing values and unreliable responses, resulting in a usable sample of 281 responses. The collected data was analyzed using the SPSS program. In the questionnaire form, statements were prepared in order to measure the variables of "Consumer Innovativeness", "Market Mavens", "Opinion Leadership", "Price Sensitivity", and "Attitudes". All of the items were measured on a 5-point Likert scale, ranging from 1 (strongly disagree) to 5 (strongly agree). The Consumer Innovativeness scale refers to the general market place instead of a specific product category. The studies where scales were used in this study were adapted from are shown in Table 1.

Table 1: Scales' Sources and Cronbach Alphas

\begin{tabular}{|l|l|c|}
\hline Scales & Studies & CRONCBACH'S ALPHA \\
\hline Consumer Innovativeness & Goldsmith, Flynn \&Goldsmith (2003) & .701 \\
\hline Market Mavens & Goldsmith et al. (2003) & .801 \\
\hline Opinion Leadership & $\begin{array}{l}\text { Goldsmith et al. (2003) } \\
\text { Lassar, Manolis \&Lassar (2005) }\end{array}$ & .860 \\
\hline Price Sensitivity & Goldsmith et al. (2003) & .801 \\
\hline Attitudes & $\begin{array}{l}\text { Cho, Lee \& Tharp (2001) } \\
\text { Zhang \& Schmitt (2001) }\end{array}$ & .825 \\
\hline
\end{tabular}

For each variable, the Cronbach's $\alpha$ was calculated for reliability. The reliability coefficients of the scales used in this study were in the range of $0.860-0.701$.

The mean score of the consumer innovation scale is quite low (Mean: 2.5 and Std. Dev.: 0.62). It can be said that consumers are not innovative. The mean score of the market maven scale is quite low (Mean: 3.5 and Std. Dev.: 0.76). Accordingly, consumers can be said to be market mavens at a low level. The mean score of the opinion leader scale is high (Mean: 3.8 and Std. Dev.: 0.74). It can be said that consumers have opinion leader tendencies.

\section{FINDINGS AND DISCUSSIONS}

\subsection{Demographic Findings}

The demographic characteristics distribution of the respondents who participated in the study is provided in Table 2.

The gender composition of the respondents was 188 (66.4\%) male and 95 (33.6\%) female. The age of the respondents ranged from 18 to 83 . About $43 \%$ of the respondents were between 30 and 39 years old. The average age was 33.65 years. $73 \%$ percent of the respondents were married $(n=205)$ and $27 \%$ of the respondents were single $(n=76)$. Household incomes of $2,001-3,000$ TL per month were reported by $33.5 \%$ of the sample number, and $53 \%$ claimed to have earned a high school degree.

Table 2: Demographic Results

\begin{tabular}{|c|c|c|c|c|c|c|c|}
\hline \multicolumn{2}{|c|}{ Demographic Characteristics } & \multirow{2}{*}{$\begin{array}{l}\mathbf{n} \\
95\end{array}$} & \multirow{2}{*}{$\begin{array}{l}\% \\
33.6\end{array}$} & \multicolumn{2}{|c|}{ Demographic Characteristics } & \multirow{2}{*}{$\begin{array}{l}\mathbf{N} \\
32\end{array}$} & \multirow{2}{*}{\begin{tabular}{l|}
$\%$ \\
11.4
\end{tabular}} \\
\hline \multirow{3}{*}{ Gender } & Female & & & \multirow{7}{*}{ Income } & Lowest Thru 1000 & & \\
\hline & Male & 188 & 66.4 & & $1001-2000$ & 88 & 31.3 \\
\hline & Total & 283 & 100 & & $2001-3000$ & 94 & 33.5 \\
\hline \multirow{5}{*}{ Age } & $18-29$ & 96 & 33.9 & & $3001-4000$ & 41 & 14.6 \\
\hline & $30-39$ & 122 & 43.1 & & $4001-6000$ & 18 & 6.4 \\
\hline & $40-50$ & 56 & 19.8 & & 6001- Over & 8 & 2.8 \\
\hline & $51-$ Over & 9 & 3.2 & & Total & 281 & 100 \\
\hline & Total & 283 & 100 & \multirow{5}{*}{ Education } & Primary & 17 & 6 \\
\hline \multirow{4}{*}{ Marital Status } & Married & 205 & 73 & & High School & 150 & 53 \\
\hline & Single & 76 & 27 & & University & 102 & 36 \\
\hline & \multirow{2}{*}{ Total } & \multirow{2}{*}{281} & \multirow{2}{*}{100} & & Masters Doctorate & 14 & 4.9 \\
\hline & & & & & Total & 283 & 100 \\
\hline
\end{tabular}




\subsection{Relationship Between Independent Variables and Demographic Variables}

Correlation (Spearman) analysis was performed to determine the relationship between Consumer Innovativeness, Market Mavens, Opinion Leadership, Affective Responses, Attitudes, Price Sensitivity, and demographic characteristics of the respondents, such as marital status, gender, income, and age. The results of these analyses are shown in Table 3.

H1: There is a statistically significant relationship between Consumers Innovation and demographic variables.

H1a: There is a statistically significant relationship between Consumers Innovation and the Gender of consumers.

H1b: There is a statistically significant relationship between Consumers Innovation and the Income of consumers.

H1c: There is a statistically significant relationship between Consumers Innovation and the Marital Status of consumers.

H1d: There is a statistically significant relationship between Consumers Innovation and the Education of consumers.

H1e: There is a statistically significant relationship between Consumers Innovation and the Age of consumers.

H4: There is a statistically significant relationship between Opinion Leadership and demographic variables.

H4a: There is a statistically significant relationship between Opinion Leadership and the Gender of consumers.

H4b: There is a statistically significant relationship between Opinion Leadership and the Income of consumers.

H4c: There is a statistically significant relationship between Opinion Leadership and the Marital Status of consumers.

H4d: There is a statistically significant relationship between Opinion Leadership and the Education of consumers.

H4e: There is a statistically significant relationship between Opinion Leadership and the Age of consumers.

H8: There is a statistically significant relationship between Market mavens and demographic variables.

H8a: There is a statistically significant relationship between Market mavens and the Gender of consumers.

H8b: There is a statistically significant relationship between Market mavens and the Income of consumers.

H8c: There is a statistically significant relationship between Market mavens and the Marital Status of consumers.

H8d: There is a statistically significant relationship between Market mavens and the Education of consumers.

H8e: There is a statistically significant relationship between Market mavens and the Age of consumers.

Table 3: The Correlation Between Consumers' Innovation and Demographical Variables and Other Variables.

\begin{tabular}{|l|l|l|l|l|l|l|}
\hline \multicolumn{2}{|c|}{} & Gender & Income & Education & $\begin{array}{l}\text { Marital } \\
\text { Status }\end{array}$ & Age \\
\hline \multirow{3}{*}{$\begin{array}{l}\text { Consumer } \\
\text { Innovativeness }\end{array}$} & Correlation Coefficient & $-.162^{* *}$ & $.138^{*}$ & $.299^{* *}$ & $.127^{*}$ & -.008 \\
\cline { 2 - 7 } & Sig. (2-tailed) & .006 & .020 & .000 & .033 & .889 \\
\cline { 2 - 7 } & $\mathrm{n}$ & 283 & 281 & 283 & 281 & 283 \\
\hline \multirow{4}{*}{$\begin{array}{l}\text { Market Mavens } \\
\begin{array}{l}\text { Opinion } \\
\text { Leadership }\end{array}\end{array}$} & Correlation Coefficient & $.122^{*}$ & .070 & .017 & -.084 & -.005 \\
\cline { 2 - 7 } & Sig. (2-tailed) & .041 & .243 & .781 & .159 & .938 \\
\cline { 2 - 7 } & $\mathrm{n}$ & 283 & 281 & 283 & 281 & 283 \\
\cline { 2 - 7 } & Correlation Coefficient & $.163^{* *}$ & .024 & $-.142^{*}$ & -.109 & .032 \\
\cline { 2 - 7 } & $\mathrm{n}$ & .006 & .690 & .017 & .067 & .597 \\
\hline
\end{tabular}

**. Correlation is significant at the 0.01 level (2-tailed).

*. Correlation is significant at the 0.05 level (2-tailed).

Table 3 shows the correlation between Consumer Innovativeness, Market Mavens, Opinion Leadership, and demographic characteristics of the respondents (marital status, gender, income, and age). According to the calculated values:

Consumer Innovativeness has a positive correlation with Income (as 0.138), Education (as 0.299), and Marital Status (as 0.127), but it has negative correlation with Gender (as -162). The hypothesis $\mathrm{H}_{1 \mathrm{a}}$ (Correlation is significant at the 0.01 level, 2-tailed), $\mathrm{H}_{1 \mathrm{~b}}$ (Correlation is significant at the 0.05 level, 2-tailed), $\mathrm{H}_{1 \mathrm{c}}$ (Correlation is significant at the 0.01 level, 2-tailed) and $\mathrm{H}_{1 \mathrm{~d}}$ (Correlation is significant at the 0.05 level, 2-tailed). These hypotheses are accepted. There was no statistically significant correlation between Consumer Innovativeness and Age. As a result of this analysis, $\mathrm{H}_{1 \mathrm{e}}$ was rejected.

Opinion Leadership has a positive correlation with Gender (as 0.163) and a negative correlated with Education (as -0.142). Hypothesis $\mathrm{H}_{4 a}$ (Correlation is significant at the 0.01 level, 2-tailed) and $\mathrm{H}_{4 \mathrm{c}}$ (Correlation is significant at the 0.05 level, 2 -tailed) 
are accepted. There was no statistically significant correlation between Opinion Leadership and Income, Marital Status, or Age. As a result of this analysis, $\mathrm{H}_{4 b}, \mathrm{H}_{4 d}$ and $\mathrm{H}_{4 \mathrm{e}}$ were rejected.

Market Mavens has a positive correlation with Gender (as 0.122). Hypothesis $\mathrm{H}_{8 a}$ (Correlation is significant at the 0.05 level, $2-$ tailed) is accepted. There was no statistically significant correlation between Opinion Leadership and Income, Education, Marital Status, or Age. As a result of this analysis, $\mathrm{H}_{8 b}, \mathrm{H}_{8 c}, \mathrm{H}_{8 \mathrm{~d}}$ and $\mathrm{H}_{8 \mathrm{e}}$ were rejected.

\subsection{Relationship Between Consumer Innovativeness and Other Variables}

Correlation (Spearman) analysis was performed to determine the relationship between Consumer Innovativeness, Market Mavens, Opinion Leadership, Attitudes, and Price Sensitivity. All hypotheses have been developed and tested to indicate the relationships between them.

$\mathrm{H}_{2}$ : There is a statistically significant relationship between Consumers Innovation and Price Sensitivity.

$\mathrm{H}_{3}$ : There is a statistically significant relationship between Consumers Innovation and Attitudes.

$\mathrm{H}_{5}$ : There is a statistically significant relationship between Consumers Innovation and Opinion Leadership.

$H_{6}$ : There is a statistically significant relationship between Opinion Leadership and Price Sensitivity.

$H_{7}:$ There is a statistically significant relationship between Opinion Leadership and Attitudes.

$H_{9}:$ There is a statistically significant relationship between Consumer Innovativeness and Market Mavens.

$H_{10}$ : There is a statistically significant relationship between Market Mavens and Opinion Leaders.

$H_{11}$ : There is a statistically significant relationship between Market Mavens and Price Sensitivity.

$H_{12}$ : There is a statistically significant relationship between Market Mavens and Attitudes .

The results showed that there are relationships between variables. The results of these analyses are shown in Table 4 .

Table 4: The Correlation Between Consumers' Innovation and Demographical Variables and the Other Variables

\begin{tabular}{|l|l|l|l|l|l|}
\hline \multicolumn{2}{|c|}{} & Market Mavens & $\begin{array}{l}\text { Opinion } \\
\text { Leadership }\end{array}$ & Attitudes & Price Sensitivity \\
\hline \multirow{3}{*}{ Consumer Innovativeness } & Correlation Coefficient & $.149^{*}$ & $-.229^{* *}$ & $.121^{*}$ & $-.404^{* *}$ \\
\cline { 2 - 6 } & Sig. (2-tailed) & .012 & .000 & .043 & .000 \\
\cline { 2 - 6 } & $\mathrm{n}$ & 283 & 283 & 282 & 283 \\
\hline \multirow{3}{*}{ Opinion Leadership } & Correlation Coefficient & $.592^{* *}$ & 1.000 & .015 & $.592^{* *}$ \\
\cline { 2 - 6 } & Sig. (2-tailed) & .000 &. & .801 & .000 \\
\cline { 2 - 6 } & $\mathrm{n}$ & 283 & 283 & 282 & 283 \\
\hline \multirow{3}{*}{ Market Mavens } & Correlation Coefficient & 1.000 & $.592^{* *}$ & $-.146^{*}$ & $.276^{* *}$ \\
\cline { 2 - 6 } & Sig. (2-tailed) &. & .000 & .014 & .000 \\
\cline { 2 - 6 } & $\mathrm{n}$ & 283 & 283 & 282 & 283 \\
\hline
\end{tabular}

**. Correlation is significant at the 0.01 level (2-tailed).

*. Correlation is significant at the 0.05 level (2-tailed).

Table 4 shows the correlation between Consumer Innovativeness, Market Mavens, Opinion Leadership, Attitudes, and Price Sensitivity. According to the calculated values:

Consumer Innovativeness a has positive correlation with Attitudes (as 0.121) and Market Mavens (as 0.149) but a negative correlation with Price Sensitivity (as -0.404) and Opinion Leadership (as -0.229). Hypothesis $\mathrm{H}_{2}$ and $\mathrm{H}_{5}$ (Correlation is significant at the 0.01 level, 2-tailed); $\mathrm{H}_{3}$ and $\mathrm{H}_{9}$ (Correlation is significant at the 0.05 level, 2-tailed) are accepted.

Opinion Leadership has a positive correlation with Market Mavens (as 0.592) and Price Sensitivity (as 0.592). Hypothesis $\mathrm{H}_{6}$ and $\mathrm{H}_{10}$ (Correlation is significant at the 0.01 level, 2-tailed) are accepted. Hypothesis $\mathrm{H}_{7}$ is rejected. We can say that there is a strong relationship (about 60\%) between Opinion Leadership and Price Sensitivity and Opinion Leadership andMarket Mavens.

Market Mavens has a negative correlation with Attitudes (as -0.119), but it has positive correlation with Price Sensitivity (as 0.276). Hypothesis $\mathrm{H}_{11}$ (Correlation is significant at the 0.01 level, 2-tailed), and $\mathrm{H}_{12}$ (Correlation is significant at the 0.05 level, 2tailed) are accepted. 


\section{CONCLUSION}

Innovativeness is especially important in the areas of marketing and consumer research because of the importance of innovators to new product success (Foxall \& Bhate, 1993). This study examined the relationships between consumer innovativeness, opinion leadership, market mavens, attitudes, price sensitivity, and demographic characteristics. The results of the analysis showed that, as hypothesized, the measures were correlated: Consumer innovation has a positive correlation with income, education, and marital status, but it has negative correlation with gender. There was no statistically significant correlation between consumer innovation and age. According to these results, higher income, higher education, females, and singles are more innovative. Opinion leadership and market mavens have a positive correlated gender. According to these results, men have more tendencies of opinion leadership and market mavens. Opinion leadership has a negative correlation with education. According to these results, less educated consumers have more tendencies of opinion leadership. There was no statistically significant correlation between opinion leadership, market mavens, and other demographic variables.

Consumer innovation has a negative correlation with price sensitivity and a positive correlation with attitudes, but it has no correlation with affective responses. Market mavens has a negative correlation with attitudes and affective responses, but it has positive correlation with price sensitivity. Opinion leadership has a positive correlation with price sensitivity. We can say that there are two strong relationships (about 60\%). First between opinion leadership and price sensitivity and the other is opinion leadership and market mavens.

Consumers with a high level of innovation have low price sensitivity. Thus, it can be said that they will be willing to pay a higher price for new products. Consumers with a positive attitude towards innovation can be said to be more innovative. It can be argued that market mavens and opinion leaders have higher price sensitivity. Although there is a relationship between variables in the study, these relations are weak. These findings are consistent with previous studies. They confirm what we know about the characteristics and behaviors of some shoppers. They also extend our knowledge of the relationship between consumer innovativeness, opinion leadership, and market mavens.

In this research, the sample is limited and only realized in Kayseri province. We used a convenience sampling method. It is a limitation of this research. For this reason, the results obtained from the research only represent the sample and cannot be generalized. The results can be generalized by using random sampling in later studies.

\section{REFERENCES}

Abratt, R., Nel, D., Nezer, C. (1995). Role of the market maven in retailing: a general marketplace influencer. Journal of Business and Psychology, 10(1), 31-55.

Andrews, M. L., Benedicktus, R. L. (2015). Are consumer innovators less resistant to change than market mavens?. In Revolution in Marketing: Market Driving Changes (pp. 223-227). Developments in Marketing Science: Proceedings of the Academy of Marketing Science. Springer, Cham.

Bagozzi, R. P. (1992). The self-regulation of attitudes, intentions, and behavior. Social Psychology Quarterly, 55(2) 178-204.

Bartels, J., Reinders, M. J. (2011). Consumer innovativeness and its correlates: a propositional inventory for future research. Journal of Business Research, 64(6), 601-609.

Barnes, S. J., Pressey, A. (2008). The virtual maven: a study of Market maven behavior in physical, Web, and virtual world channels. Enhancing Knowledge Development in Marketing, 19, 445-456.

Bidar, R., Watson, J., Barros, A. P. (2016). Literature review to determine environmental and cognitive factors underlying user value cocreation behaviour. PACIS 2016 Proceedings. 327-336.

Blake, B. F., Neuendorf, K. A., Valdiserri, C. M. (2003). Innovativeness and variety of internet shopping. Internet Research, 13(3), 156-169.

Brancaleone, V., Gountas, J. (2007). Personality characteristics of market mavens. ACR North American Advances.

Childers, T. L. (1986). Assessment of the psychometric properties of an opinion leadership scale. Journal of Marketing Research, 184-188.

Cho, C. H., Lee, J. G., Tharp, M. (2001). Different forced-exposure levels to banner advertisements. Journal of Advertising Research, 41(4), 45-56.

Clark, R. A., Goldsmith, R. E. (2005). Market mavens: psychological influences. Psychology \& Marketing, 22(4), 289-312.

Clark, R. A., Goldsmith, R. E. (2006). Interpersonal influence and consumer innovativeness. International Journal of Consumer Studies, 30(1), 3443.

Claudy, M. C., Garcia, R., O'Driscoll, A. (2015). Consumer resistance to innovation-a behavioral reasoning perspective. Journal of the Academy of Marketing Science, 43(4), 528-544.

Dickerson, M., Gentry, J. W. (1983). Characteristics of adopters and non-adopters of home computers. Journal of Consumer Research, 10(2), 225-235. 
Duvel, G. H., Williams, R. F. (2005). The nature and determinants of opinion leadership in Lesotho. South African Journal of Agricultural Extension, 34(2), 260-274.

Eiamkanchanalai, S., Assarut, N. (2016). Consumer innovativeness and opinion leadership: revisiting consumer characteristics in new product diffusion model. Global Business and Economics Review, 18(1), 15-27.

Feick, L. F., Price, L. L. (1987). The market maven: a diffuser of marketplace information. The Journal of Marketing, 21(2), 83-97.

Ferreira de Lara, F., Neves Guimarães, M. R. (2014). Competitive priorities and innovation in SMEs: a Brazil multi-case study. Journal of Technology Management \& Innovation, 9(3), 51-64.

Fort-Rioche, L., Ackermann, C. L. (2013). Consumer innovativeness, perceived innovation and attitude towards "neo-retro"-product design. European Journal of Innovation Management, 16(4), 495-516.

Foxall, G. R., Goldsmith, R. E., Brown, S. (1998). Consumer psychology for marketing (Vol. 1). Cengage Learning EMEA.

Jain, S. P., Posavac, S. S. (2001). Prepurchase attribute verifiability, source credibility, and persuasion. Journal of Consumer Psychology, 11(3), 169-180.

Gatignon, H., Robertson, T. S. (1985). A propositional inventory for new diffusion research. Journal of Consumer Research, 11(4), 849-867.

Gilly, M. C., Zeithaml, V. A. (1985). The elderly consumer and adoption of technologies. Journal of Consumer Research, 12(3), 353-357.

Goldsmith, R. E., Stith, M. T., White, J. D. (1987). Race and sex differences in self-identified innovativeness. Journal of Retailing, 63(4), 411-425.

Girardi, A., Soutar, G. N., Ward, S. (2005). The validation of a use innovativeness scale. European Journal of Innovation Management, 8(4), 471481.

Goldsmith R. E., Newell, S. J. (1997). Innovativeness and price sensitivity: managerial, theoretical and methodological issues. Journal of Product \& Brand Management, 6(3), $163-174$.

Goldsmith, R. E., Moore, M. A., Beaudoin, P. (1999). Fashion innovativeness and self-concept: a replication. Journal of Product \& Brand Management, 8(1), 7-18.

Goldsmith, R. E., Foxall, G. R. (2003). The measurement of innovativeness. In the International handbook on innovation (pp. 321-330).

Goldsmith, R. E., Flynn, L. R., Goldsmith, E. B. (2003). Innovative consumers and market mavens. Journal of Marketing Theory and Practice, 11(4), 54-65.

Goldsmith, R. E., Kim, D., Flynn, L. R., Kim, W. M. (2005). Price sensitivity and innovativeness for fashion among Korean consumers. The Journal of Social Psychology, 145(5), 501-508.

Goldsmith, R. E., Clark, R. A., Goldsmith, E. B. (2006). Extending the psychological profile of market mavenism. Journal of Consumer Behaviour, 5(5), 411-419.

Goodey, C., East, R. (2008). Testing the market maven concept. Journal of Marketing Management, 24(3-4), 265-282.

Grewal, R., Mehta, R., Kardes, F. R. (2000). The role of the social-identity function of attitudes in consumer innovativeness and opinion leadership. Journal of Economic Psychology, 21(3), 233-252.

Hirunyawipada, T., Paswan, A. K. (2006). Consumer innovativeness and perceived risk: implications for high technology product adoption. Journal of consumer marketing, 23(4), 182-198.

Hoffmann, S., Soyez, K. (2010). A cognitive model to predict domain-specific consumer innovativeness. Journal of Business Research, 63(7), 778785.

Hoyer, W. D., Stokburger-Sauer, N. (2007). A comparison of antecedents and consequences of market mavens and opinion leaders. In: Bayón T., Herrmann A., Huber F. (eds)Vielfalt und einheit in der marketingwissenschaft, 215-236.

Im, S., Bayus, B. L., Mason, C. H. (2003). An empirical study of innate consumer innovativeness, personal characteristics, and new-product adoption behavior. Journal of the Aademy of Marketing Science, 31(1), 61-73.

Jordaan, Y., Simpson, M. N. (2006). Consumer innovativeness among females in specific fashion stores in the Menlyn shopping centre. Journal of Consumer Sciences, 34(1), 32-40.

Kaushik, A. K., Rahman, Z. (2014). Perspectives and dimensions of consumer innovativeness: a literature review and future agenda. Journal of International Consumer Marketing, 26(3), 239-263.

Labay, D. G., Kinnear, T. C. (1981). Exploring the consumer decision process in the adoption of solar energy systems. Journal of Consumer Research, 8(3), 271-278.

Lassar, W. M., Manolis, C., Lassar, S. S. (2005). The relationship between consumer innovativeness, personal characteristics, and online banking adoption. International Journal of Bank Marketing, 23(2), 176-199. 
Laukkanen, T. (2016). Consumer adoption versus rejection decisions in seemingly similar service innovations: the case of the Internet and mobile banking. Journal of Business Research, 69(7), 2432-2439.

Lennon, S. J., Kim, M., Johnson, K. K., Jolly, L. D., Damhorst, M. L., Jasper, C. R. (2007). A longitudinal look at rural consumer adoption of online shopping. Psychology \& Marketing, 24(4), 375-401.

Mann, B. J. S., Sahni, S. K. (2012). Profiling adopter categories of internet banking in India: an empirical study. Vision, 16(4), $283-295$.

Martinez, E., Polo, Y., Flavian, C. (1998). The acceptance and diffusion of new consumer durables: differences between first and last adopters. Journal of Consumer Marketing, 15(4), 323-342.

Pagani, M. (2007). A vicarious innovativeness scale for $3 G$ mobile services: integrating the domain specific innovativeness scale with psychological and rational indicators. Technology Analysis \& Strategic Management, 19(6), 709-728.

Porter, C. E., Donthu, N. (2006). Using the technology acceptance model to explain how attitudes determine Internet usage: the role of perceived access barriers and demographics. Journal of Business Research, 59(9), 999-1007.

Rogers, E. M., Shoemaker, P. (1971). Communication of innovations. New York: Free Press, 1971.

Ruvio, A., Shoham, A. (2007). Innovativeness, exploratory behavior, market mavenship, and opinion leadership: an empirical examination in the Asian context. Psychology \& Marketing, 24(8), 703-722.

Sarathy, P. S., Patro, S. K. (2013). The role of opinion leaders in high-involvement purchases: an empirical investigation. South Asian Journal of Management, 20(2).

Sarathy, P. S. (2011). Organizational innovations in the real-estate industry using AHP. International Journal of Organizational Innovation, 4(1).

Shiffman, L., O’Cass, A., Paladino, A., Carlson, J. (2014). Chapter 11: the influence of culture on consumer behaviour. Consumer Behaviour (6th ed.). Australia: Pearson.

Shih, C. F., Venkatesh, A. (2004). Beyond adoption: development and application of a use-diffusion model. Journal of Marketing, 68(1), 59-72.

Shimp, T. A., Dunn, T. H., Klein, J. G. (2004). Remnants of the US Civil War and modern consumer behavior. Psychology \& Marketing, 21(2), 7591.

Shoham, A., Ruvio, A. (2008). Opinion leaders and followers: a replication and extension. Psychology \& Marketing, $25(3), 280-297$.

Steenkamp, J. B. E., Hofstede, F. T., Wedel, M. (1999). A cross-national investigation into the individual and national cultural antecedents of consumer innovativeness. The Journal of Marketing, 63(2), 55-69.

Steenkamp, J. B. E., Burgess, S. M. (2002). Optimum stimulation level and exploratory consumer behavior in an emerging consumer market. International Journal of Research in Marketing, 19(2), 131-150.

Steenkamp, J. B. E., Gielens, K. (2003). Consumer and market drivers of the trial probability of new consumer packaged goods. Journal of Consumer Research, 30(3), 368-384.

Stokburger-Sauer, N. E., Hoyer, W. D. (2009). Consumer advisors revisited: what drives those with market mavenism and opinion leadership tendencies and why?. Journal of Consumer Behaviour, 8(2-3), 100-115.

Sun, T., Youn, S., Wu, G., Kuntaraporn, M. (2006). Online word-of-mouth (or mouse): an exploration of its antecedents and consequences. Journal of Computer-Mediated Communication, 11(4), 1104-1127.

Tellis, G. J., Yin, E., Bell, S. (2009), Global consumer innovativeness: cross-country differences and demographic commonalities. Journal of International Marketing, 17 (2), 1-22.

Williams, T. G., Slama, M. E. (1995). Market mavens\# purchase decision evaluative criteria: implications for brand and store promotion efforts. Journal of Consumer Marketing, 12 (3), 4-21.

Uhl, K., Andrus, R., Poulsen, L. (1970). How are laggards different? An empirical inquiry. Journal of Marketing Research,7(1), 51-54.

Vandecasteele, B., Geuens, M. (2010). Motivated consumer innovativeness: concept, measurement, and validation. International Journal of Research in Marketing, 27(4), 308-318.

Venkatraman, M. P. (1991). The impact of innovativeness and innovation type on adoption. Journal of Retailing, $67(1), 51$.

Vishwanath, A. (2005). Impact of personality on technology adoption: an empirical model. Journal of the American Society for Information Science and Technology, 56(8), 803-811.

Wiedmann, K. P., Walsh, G., Mitchell, V. W. (2001). The Mannmaven: an agent for diffusing market information. Journal of Marketing Communications, 7(4), 195-212.

Xie, Y., Singh, N. (2007). The impact of young adults' socialization on consumer innovativeness, Journal of Customer Behavior, 6(3), $229-248$.

Zhang, S., Schmitt, B. H. (2001). Creating local brands in multilingual international markets. Journal of Marketing Research, 38(3), 313-325. 